Wzniostosć i makabra w literackich obrazach śmierci, red. Michał Kuran, Łódź 2014, „Analecta Literackie i Językowe", t. IV.

ANNA KaŹMIERSKA ${ }^{1}$

Uniwersytet Łódzki

\title{
ŚMIERĆ UPOETYCZNIONA — LITERACKIE OBRAZY ŚMIERCI SAMOBÓJCZYCH
}

W Stowniku języka polskiego PWN samobójstwo (łac. suicidium) definiowane jest jako „celowe odebranie sobie życia” oraz „działanie na własną szkodę”. Encyklopedia Powszechna Orgelbranda z XIX wieku ${ }^{3}$ podaje informację o pozbawieniu ludzi, którzy targnęli się na własne życie, prawa do chrześcijańskiego pochówku oraz o uznaniu testamentów samobójców za akty niemające jakiejkolwiek mocy prawnej. Wyjaśnienia te z pewnością są zgodne z powszechnym pojmowaniem samobójstwa jako czynu niemoralnego, naruszającego porządek natury, pokazującego ludzką słabość i noszącego znamiona autodestrukcji, a przede wszystkim niezgodnego z religią chrześcijańską. Największy z Kościołów wyznających wiarę chrześcijańską, Kościół rzymskokatolicki, w którym Bóg jest jedyną siłą mogącą życie dać i odebrać, czyn suicydalny uznaje za grzech śmiertelny, najwyższy występek przeciw Stwórcy i Jego prawom. Nie tylko w chrześcijaństwie samobójstwo jest napiętnowane. Także w judaizmie, spirytyzmie, islamie czy w wierzeniach licznych ludów afrykańskich ${ }^{4}$ samobójstwo to czyn grzeszny niszczący związek człowieka z Istotą Najwyższą. Nie tylko religia, ale też społeczeństwo, środowisko narzuca moralny obowiązek życia i dlatego nie aprobuje samobójstwa.

\footnotetext{
${ }^{1}$ Anna Kaźmierska — rocznik '91. Studentka II roku filologii polskiej na Uniwersytecie Łódzkim (studia magisterskie), specjalizacje nauczycielska, grafika komputerowa i komunikowanie publiczne. Zainteresowania badawcze wiążą się z literaturą wieku XIX i XX, przede wszystkim dotyczą dzieł literackich epoki pozytywizmu i Młodej Polski, oscylują wokół poznawania literacko rozpisanych bohaterów ze środowisk aktorskich oraz należących do cyganerii artystycznej. Autorka zainteresowana jest także postawą bohatera literackiego w zetknięciu z sytuacjami granicznymi (wojna, śmierć, cierpienie, ale też kryzys egzystencjalny). Najwięcej uwagi w swych rozważaniach poświęca zjawisku nie mieszczącemu się w granicach żadnej epoki — dandyzmowi oraz wszelkim próbom podejmowanym przez postaci wybranych utworów literackich estetyzacji tego, co banalne i przyziemne. Sama chciałaby choć przez chwilę uczestniczyć w intelektualnych dysputach bohaterów Próchna Berenta lub znaleźć się w Krakowie z początku XX wieku, by poznać Witkacego i Stanisława Przybyszewskiego.

2 Stownik języka polskiego PWN [online], dostęp 4 sierpnia 2013, dostępny: <http://sjp.pwn.pl/ slownik/2519017/samobójstwo>.

${ }^{3}$ K. W. Wójcicki, Samobójstwo, [w:] Encyklopedia powszechna, t. 22, Warszawa 1866, s. 877.

${ }^{4} \mathrm{O}$ stosunku religii ludów Afryki do samobójstwa pisze R. Kapuściński: „W wierzeniach niektórych ludów Afryki, np. ludu Ashanti, samobójcy byli karani po śmierci. Nie tylko duchy przodków są rozgniewane, także żyjący. Okazują to, ścinając im głowę" (R. Kapuściński, Heban, Warszawa 2002, s. 38). Więcej informacji na temat stanowisk innych religii wobec samobójstwa w artykule Mirosława Kropidłowskiego, Religie wobec samobójstwa [online], dostęp 4 sierpnia 2013, dostępny: <http://www. racjonalista.pl/kk.php/s,3948>.
} 
Głos literatury wieku XIX i XX w tej sprawie jest inny. Wynika to między innymi z rosnącej popularności buddyzmu oraz inspiracji czerpanych z kultury i filozofii Wschodu (zwłaszcza w XIX stuleciu), które samobójstwo waloryzowały inaczej (vide Hertenstein z Próchna Wacława Berenta, który, zachwycony propagowanym przez religie buddyjskie pogrążeniem się w nicość, pragnie w wyestetyzowany sposób popełnić samobójstwo $)^{5}$. Wiąże się to także z nowymi poglądami filozoficznymi narodzonymi w Europie - pesymizmem Schopenhauera (z którego czerpali dekadenci) czy nihilizmem nietzscheańskim. Należy jednak pamiętać, że filozofie te posłużyły tylko częściowo jako źródło budujące światopogląd — Schopenhauer nie pochwalał samobójstwa, stosunek Nietzschego wobec tego czynu można określić jako niejednoznaczny: z jednej strony jako autor traktatu o woli mocy był zwolennikiem silnej (także psychicznie) jednostki, z drugiej strony przyznawał człowiekowi moralne prawo do decydowania o tym, kiedy ma umrzeć. Używał nawet określenia freitot, czyli dobrowolna śmierć. Niejednokrotnie też stwierdzał, że „Myśl o samobójstwie jest wielkim pocieszeniem. Dzięki niej udaje się przetrwać wiele złych nocy”. Dla potrzeb tego artykułu (omawiana dalej śmierć samobójcza Petroniusza z Quo vadis Henryka Sienkiewicza) warto zwrócić także uwagę na podejście greckich filozofów, którzy uważali, że człowiek sam powinien decydować o tym, kiedy ma umrzeć (stoik Zenon żyjący na przełomie IV i III w. p. n.e. uważał, że samobójstwo to godny szacunku czyn wtedy, gdy choroba sprawia, że śmierć staje się bardziej atrakcyjna niż życie). Dla wielu starożytnych śmierć miała być hołdem dla życia.

W wiekach kolejnych, które nastąpiły po antyku, zachowania suicydalne są waloryzowane negatywnie. W średniowieczu, w którym teocentryzm, wiara i Bóg są odpowiedzią na wszystkie wątpliwości, samobójstwo jest pojmowane jako gwałt na istocie ludzkiej i prawach Bożych. Renesansowy powrót do stoickiej i epikurejskiej filozofii oraz do wiary w dobroć ludzi i harmonię istnienia sprawia, że samobójstwo staje się wykroczeniem wobec piękna życia. Barokowe przekonanie o marności świata, życiu jako dążeniu do śmierci i końcu postrzeganym jako najwyższa sprawiedliwość sprawiały, że samobójstwo, podobnie jak w średniowieczu, stawało się sprzeciwem wobec woli Bożej. W oświeceniu, które było okresem wiary w potęgę ludzkiego umysłu, niepoddającego się przeciwnościom i czyniącego z człowieka istotę silną, zrównoważoną, myślącą logicznie, nie było miejsca na akt niemocy, jakim jest samobójstwo.

To romantyzm jako pierwszy uczynił z samobójstwa sposób radzenia sobie z rzeczywistością. Jednostka XVIII i XIX wieku musi zmierzyć się z takimi problemami

\footnotetext{
${ }^{5}$ Należy podkreślić, że choć z buddyzmu pochodzą takie sformułowania jak nirwana i pogrążenie się w nicość, które były wykorzystywane przez ludzi w XIX wieku jako synonimy samobójstwa, w religii buddyjskiej oznaczają stan wyzwolenia od myśli i uczuć w czasie modlitwy oraz odnoszą się do miejsca, w którym znajdą się wyznawcy po śmierci, lecz nie oznaczają, że religia Buddy aprobuje akt samobójczy. Określenia te zostały jedynie zaczerpnięte z religii Wschodu i uznane za synonimy samobójstwa wyrażające potrzebę odcięcia się od świata i pogrążenia się w niebyt. W buddyzmie, zgodnie z „Pierwszą Szlachetną Zasadą", śmierć nie jest środkiem, by z cierpieniem, jakim jest życie, skończyć.
} 
i tragediami jak: wojna, cierpienie, śmierć bliskich, brak swobody politycznej i społecznej, konwenanse, nieodwzajemniona miłość czy rozterki natury egzystencjalnej. Pierwszym literackim przykładem samobójstwa jako końca cierpienia udręczonej niespełnioną miłością jednostki jest utwór Johanna Wolfganga Goethego Cierpienia mtodego Wertera (1774). To literackie wydarzenie stało się także wydarzeniem społecznym, bowiem po przeczytaniu lektury niemieckiego wieszcza wielu młodych mężczyzn dokonywało tzw. samobójstwa imitacyjnego — z imieniem nieodwzajemniającej uczuć kobiety na ustach, zadawali sobie śmierć niejednokrotnie ubrani na wzór werterowski (żółty frak, niebieska kamizelka). W polskiej literaturze samobójstwem kończy się życie Gustawa z Dziadów cz. IV (1823) Adama Mickiewicza, także spowodowane nieszczęśliwą miłością.

W Królestwie Polskim popełniali samobójstwa młodzi oficerowie, którzy wprost z armii napoleońskiej dostali się do armii dowodzonej przez okrutnego księcia Konstantego. W latach 1816-1819 było tych samobójstw podobno aż 49. Wstrząsały opinią publiczną, odnotowywano je w pamiętnikach, wspominał o nich Kazimierz Brodziński w swej słynnej mowie z maja 1831 roku, ale w literaturze pięknej znalazły odbicie tylko w groteskowym obrazie lasu samobójców z Poema Piasta Dantyszka herbu Leliwa o piekle (1839) Juliusza Słowackiego. Przykładem śmierci samobójczej poniesionej w imię ojczyzny jest śmierć tytułowego bohatera Kordiana (1834) Słowackiego.

Przywołane postaci w podjęciu decyzji o popełnieniu samobójstwa kierują się albo motywacją patriotyczną, albo motywacją wynikającą z nieszczęśliwej, nieodwzajemnionej miłości. Nie ma miejsca na pytania o sens osobniczego istnienia, na iście hamletowską refleksję: żyć czy nie żyć. Dopiero w pozytywizmie, a w pełni w okresie modernizmu w literaturze pojawiają się ludzie wyalienowani, dla których samobójstwo jest ucieczką od poniesionej klęski, finałem przegranego życia lub efektem przeczącej odpowiedzi na pytanie, czy warto żyć i czy życie ludzkie ma sens. Obok Toporka i jego córki, bohaterów noweli Sienkiewicza Za chlebem (1880), których śmierć była efektem skrajnej nędzy, w jakiej żyli, oraz bohaterów Trylogii (m.in. Wołodyjowskiego), którzy stracili życie z miłości do kraju, pojawiają się jednostki decydujące się na popełnienie samobójstwa z powodu prawdziwych, bądź wyolbrzymionych komplikacji w sferze miłości, problemów z odnalezieniem swego miejsca w społeczeństwie, z niemożności zaakceptowania obrazu własnego „ja”. Takimi bohaterami są Franka z Chama (1888) Elizy Orzeszkowej, która popełnia samobójstwo z powodu zawiedzionych uczuć, błazen ze Śmierci Stańczyka (1889) Jana Kantego Turskiego załamany odbieranym mu prawem do człowieczeństwa i z tej przyczyny dokonujący czynu suicydalnego, Alojzy Darwid z Argonautów (1900) Orzeszkowej, poszukujący szczęścia i nieodnajdujący go czy wreszcie zwiedziony i zawiedziony miłością i ludzkim egoizmem Wokulski z Lalki (wyd. osobne 1890 rok) Bolesława Prusa. Samobójstwa pozytywistycznych bohaterów, ukazujące rozdźwięk pomiędzy ideami postępu i rozwoju a rzeczywistością, przygotowały grunt pod neoromantyczne postawy, które w Młodej Polsce realizowały się u takich bohaterów, jak Płoszowski z Bez dogmatu (1891) Sienkiewicza, Petroniusz z Quo vadis czy postaci z Próchna (1901) Berenta. 
Rezygnacja z życia, ukazana w licznych dziełach doby romantyzmu, pozytywizmu, Młodej Polski i dwudziestolecia międzywojennego, nie da się ująć w ściśle określone ramy, nie może być oceniona jednoznacznie, wreszcie nie powinna być pojmowana jako oznaka słabości. Epoki te, za najwyższe wartości uznające miłość, artyzm, piękno, prowokację, uczyniły z samobójstwa ceremonię wyzwolenia ze sztywnych ram, manifestację swobody decydowania o sobie, akt chwalebnego odejścia ze świata. Nieszczęśliwa miłość w romantyzmie, dekadencki wyraz poczucia bezsensu życia, dandysowska umiejętność zejścia ze sceny w odpowiednim czasie czy demonstracja niezgody na rzeczywistość nękaną wojnami w XX wieku, jako przyczyny podejmowania przez ludzi XIX i XX stulecia prób samobójczych, uczyniły z odebrania sobie życia akt najwyższej wolności i nadały mu znamiona sztuki, a właściwie jej ostatniego aktu.

W niniejszej rozprawie opisane zostaną próby poetyzacji tego, co do tej pory pojmowane było jako szkaradne, występne i nienaturalne, a co w okresie przede wszystkim Młodej Polski było dowodem najpełniejszego samouświadomienia.

Zaczynam od Quo vadis Sienkiewicza, które, choć chronologicznie należy do okresu pozytywizmu, to przedstawia starożytną antycypację bohatera dandysowskiego posiadającego cechy znamienne także dla bohaterów modernistycznych. $\mathrm{Z}$ uwagi na to, że dandyzm bohatera powieści Sienkiewicza nie jest tematem niniejszej pracy, pomijam tu cechy Petroniusza, które wskazywałyby na jego przynależność do tej postawy. Wystarczy powiedzieć, że rzymski arbiter elegantiarum, esteta i filozof, dbający o piękno i szukający go w każdym szczególe, najpełniej swój dandyzm objawia w chwili śmierci.

Petroniusz decyduje się na popełnienie samobójstwa, bo wie, że właśnie teraz nadszedł na to odpowiedni moment. Jak prawdziwy dandys, zdaje sobie sprawę z tego, kiedy należy zejść ze sceny życia. W jego śmierci nie ma nic przypadkowego, jest ona harmonijnym (a przez to wydaje się tak właściwym) dopełnieniem pięknej egzystencji. Petroniusz-dandys reżyseruje widowisko swego umierania tak, jak doskonale kierował życiem. Każdy szczegół musi być dopracowany, jak na przykład to, że goście Petroniusza muszą przestępować próg jego domu prawą nogą. Nad przebiegiem przygotowań czuwa sam arbiter elegantiarum, dając nagrody tym, których praca go zadowala, zaś tych, którzy nie spełniają jego oczekiwań, karząc lekką chłostą. Doglądając przygotowań do uczty, na której dopełni żywota, manifestuje nie swoją słabość, nie tchórzostwo, nie nieumiejętność radzenia sobie ze zmianami. Dzięki starannie wyreżyserowanej śmierci demonstruje on swoją wolność, umiar i jednocześnie udowadnia, że tak jak zachwycająco żył, tak pięknie potrafi też umrzeć.

Petroniusz jest szczęśliwy i spełniony, spokojnie oznajmia Eunice swą wolę, by jego dobra ziemskie od tej pory należały do niej. Parę godzin przed śmiercią stwierdza, że chce umrzeć pogodnie i jako prawdziwy esteta cieszy się tym, co należy do życia, do sfery piękna i sztuki: posągową urodą ukochanej kobiety. Czekając na ostatnią chwilę, docenia obecną, nawet jeśli tylko przysłuchuje się poruszonym przez powiew wiatru liściom buku. 
Poetyczne i radosne widowisko, pełne kolorów, dźwięków, smaków przygotowuje Petroniusz dla swych licznych przyjaciół — jak każdy dandys pragnie mieć bowiem wielu widzów, którzy obserwują i podziwiają tego, którego życie i śmierć były sztuką samą w sobie. Każdy z uczestników owego „symposionu” " ma świadomość tego, że przybywa na ucztę przewyższającą wyrafinowaniem i przepychem „nudne i barbarzyńskie" uczty u Nerona. Nikt nie zdaje sobie sprawy, że będzie to ostatnie spotkanie, tym bardziej nie mogą się tego domyślić, patrząc na radosny uśmiech widoczny na twarzy gospodarza, który, jako zręczny aktor i reżyser nie tylko buduje napięcie, pragnąc wywołać zaskoczenie w zgormadzonych wiadomością o swej śmierci, ale też pragnie, by każdy wkraczał do jego domostwa radosny i przygotowany na świętowanie, a nie opłakiwanie. Goście już po chwili od przekroczenia progu domu Petroniusza czują się swobodnie, pewnie, radośnie, ponieważ przepych nie wiązał się tu z przesadą, wyrazistość z dosadnością, wyraźne kolory z jaskrawością.

Nakrycie stołu jaśniało przepychem, lecz przepych ów nie raził, nie ciężył nikomu [...]. Wesołość i swoboda rozlewały się wraz z wonią fiołków po Sali. Goście wchodząc tu czuli, że nie zawiśnie nad nimi ni przymus, ni groźba, jak to bywało u cezara [...]. Wraz też na widok świateł, bluszczowych kruż, win lodowaciejących w śniegowej pościeli i wyszukanych potraw rozochociły się serca biesiadników\$.

Petroniusz godnie spełnia obowiązi gospodarza: rozdaje uśmiechy swym gościom, przynagla ich do raczenia się trunkami i potrawami, dyskutuje o najnowszych wydarzeniach w polityce, sztuce, filozofii. „Rozmowa jego była jak promień słońca, który coraz to inny przedmiot oświeca, lub jak letni powiew, który porusza kwiaty w ogrodzie"

Opis świętowania w domu patrycjusza rzymskiego silnie oddziałuje na zmysły. Pobudzony jest zmysł węchu wyczuwającego zapach „wieńców z róż”10 i fiołków oraz zmysł smaku w wyobraźni delektujący się sprowadzonymi z odległych krajów świeżymi owocami, wykwintnymi daniami i najlepszego gatunku winami. Wzrok rejestruje bogate, nasycone, wyraźne kolory: złoto półmisków, szkarłat tkanin, czerwień krwi. W uszach rozbrzmiewają dźwięki cytry i radosne głosy wykonujące pieśn ku czci Harmodiosa ${ }^{11}$. Podobnie jak oczy biesiadujących, oko czytelnika cieszy się widokiem tańczących postaci. Znawca i wielbiciel sztuki w ostatnim akcie swego życia otacza się tym, co zawsze było dla niego ważne, co czyniło jego egzystencję bardziej wzniosłą i co uszczęśliwi go w chwili śmierci. Widoczna jest tu dandysowska potrzeba czynienia każdej chwili, nawet jeśli jest tą ostatnią, zachwycającą.

Petroniusz skrupulatnie realizuje poszczególne części misternego planu swej ostatniej uczty, począwszy od wspólnego biesiadowania, poprzez podzielenie się winem ze wspólnego, bogato zdobionego kielicha, aż po finalną przemowę i sam samobójczy akt.

\footnotetext{
${ }^{6}$ Tu: spotkania, uczty.

${ }^{7}$ H. Sienkiewicz, Quo vadis, wstęp B. Mazan, Warszawa 1995, s. 532.

${ }^{8}$ Tamże, s. 533.

${ }^{9}$ Tamże.

${ }^{10}$ Tamże, s. 532.

${ }^{11}$ Tamże, s. 536.
} 
Ta śmierć nie jest wydarzeniem smutnym, nie nosi znamion żałoby. Wręcz przeciwnie - Petroniusz wysłuchuje wyroku śmierci z niczym niezmąconą pogodą, cieszy się na myśl o zrealizowaniu swych zamierzeń, w czasie przygotowań „na twarzy jego nie [...] widać najmniejszej troski” ${ }^{12}$, zaś w trakcie uczty zachowuje poczucie humoru i dystans do świata. Upomina przyjaciół, by cieszyli się, zamiast zdumiewać, bowiem „starość, bezsilność smutni to towarzysze ostatnich lat życia” ${ }^{13}$. Dlatego Petroniusz odchodzi wtedy, gdy jest u szczytu siły, sprawności, urody, nie czekając na to, by upływające lata przysporzyły mu problemów, chorób i ułomności, a nade wszystko brzydoty i spospolicenia. To, czego pragnie patrycjusz rzymski, wyraża w jednym zdaniu: "Chcę się weselić, pić wino, słuchać muzyki, patrzeć na te oto boskie kształty [...], a potem zasnąć $\mathrm{z}$ uwieńczoną głową" ${ }^{14}$. $\mathrm{O}$ to samo prosi swych gości.

W chwili śmierci Petroniusz zachowuje umiejętność ironizowania i tworzenia zgrabnych bon motów (to też cecha dandysowska!), co najpełniej objawia się, gdy odczytuje list do Nerona. Oprócz inteligentnych impertynencji w liście swym Petroniusz zawiera zdanie najlepiej określające to, czym było jego życie i wyjaśniające, dlaczego decyduje się z niego zrezygnować: „Życie jest wielkim skarbem [...], jam zaś z owego skarbu umiał najcenniejsze wybierać klejnoty" ${ }^{15}$. Skoro nie jest w stanie już więcej otrzymywać od życia tego, co najlepsze, postanawia odejść, nie potrafiąc zgodzić się na to, co tylko przeciętne, banalne.

W odebraniu sobie życia przez Petroniusza nie ma nic odrażającego — krew spływająca po jego rękach i łącząca się we wspólną rzekę z krwią ukochanej Eunice zachwyca intensywnością barwy i kształtem, jaki tworzy na ciele. Oboje są spokojni, zachwycający, wyglądają jak bogowie. Życie upływa z Petroniusza delikatnie, powoli i pięknie, akt ten nie jest skażony odpychającymi, makabrycznymi aspektami zjawiska śmierci.

Ostatnia uczta u Petroniusza to feeria zmysłowości, radości, lekkości i harmonii, zaś jego samobójstwo to paradoksalnie największy manifest życia. W ostatnich chwilach bowiem Petroniuszowi towarzyszy to, co tak ukochał za życia: wino, muzyka i piękno kobiecego ciała. I choć Petroniusz nie dokończył swego finalnego zdania, zarówno dla ówcześnie biesiadujących, jak i dla współczesnych czytelników wiadome jest, że razem z odejściem Petroniusza i jego Eunice kończy się poezja, piękno, niczym niezmącona rozkosz i radość z każdej chwili.

$\mathrm{Na}$ decyzję Petroniusza wpływ miały niewątpliwie nie tylko okoliczności zewnętrzne (oskarżenie o współudział w spisku na życie Nerona), ale też światopogląd, wewnętrzna organizacja życia psychicznego człowieka dokonującego hierarchizacji wartości zgodnie z wyznawaną filozofią. Petroniusz jako praktyk epikureizmu narzędziem oceny życia i zachowania czyni etykę szczęścia — podstawowym zadaniem człowieka

\footnotetext{
${ }^{12}$ Tamże, s. 531.

${ }^{13}$ Tamże, s. 534.

${ }^{14}$ Tamże.

${ }^{15}$ Tamże.
} 
jest upatrywanie szczęścia w przyjemnościach pojmowanych nie hedonistycznie. Wartościowe życie to dla patrycjusza rzymskiego kontemplowanie przyjemności zgodnych z teorią Epikura: radość samego życia, współodczuwanie ludzkiej radości i docenianie piękna tworów natury oraz przyjemności czynne duchowe (czytanie, obcowanie ze sztuką, intelektualne dysputy) oraz fizyczne (delektowanie się wyśmienitym winem, wybornymi potrawami, ale też pięknem fizycznego aktu miłosnego). Gdy Petroniusz dochodzi do wniosku, że ucieczka z Rzymu przed gniewem Nerona nie pozwoliłaby mu czerpać radości z życia w stopniu go satysfakcjonującym, zaś pozostanie w Wiecznym Mieście naraziłoby go na niegodną, nieestetyczną śmierć, postanawia zakończyć życie w chwili, gdy posiada wszystko, co jest mu potrzebne do szczęścia. I choć Gajusz Petroniusz jest krytykowany przez stoików, a wysoką pozycję w cesarstwie uzyskał, gdy Neron był już znudzony stoickim Seneką, śmierć Arbitra zdaje się być także spełnieniem jednego z podstawowych założeń szkoły Chryzypa z Soloi: Petroniusz odcina emocje od zdarzeń zewnętrznych, a jego ostatnia uczta jest manifestacją stoickiego postulatu utrzymywania stanu spokojnego szczęścia niezależnie od zewnętrznych warunków.

Atmosfera wesela i niefrasobliwej beztroski w chwili śmierci nie towarzyszy bohaterom pozostałych utworów, które stały się przyczynkiem do analizy zagadnienia poetycznej śmierci. Potrzeba pięknego odejścia ze świata nie wynika ze świadomości dobrze przeżytego życia i pragnienia pięknego jego zakończenia, nie łączy się, jak to było w przypadku Petroniusza, z radością i zachwytem nad światem, muzyką i winem.

W przypadku Siennickiego, bohatera powieści Gabrieli Zapolskiej Fin-de-siecle'ist$k a$, decyzja o samobójstwie jest efektem rozczarowania życiem, wynika ze świadomości schyłkowości czasów i przekonania o bliskim upadku jednostki ludzkiej. Siennicki staje się dla Heleny Świeżawskiej, tytułowej bohaterki powieści, przewodnikiem życia, duchowym mistrzem, nosicielem jedynej prawdy o świecie skażonym brakiem wartości, kryzysem wiary, kultury i etyki, nastawionym na cielesne uciechy. Pragnienie śmierci i opinię o otaczającej rzeczywistości Siennicki wyraża w tych słowach:

Gardzę nim [ciałem — przyp. A.K.], słyszysz, gardzę! Gdybym może raz jeden odczuł owe „opiewane przez wieszczów” rozkoszne upojenia, może mógłbym się cofnąć... Nie chcę, nie chcę, mógłbym jeszcze się wlec z tym wstrętnym workiem ciała dokoła mej istoty, nie, nie, a potem... Lombroso ${ }^{16} \ldots$ precz z życiem... dziedziczność, choroby, obłuda, błądzenie w ciemności, codzienne pożywienie, rwanie się o kawałek chleba, nie, nie, niech wszystko wyginie, ty, ja, świat cały! ${ }^{17}$

Jak prawdziwy dekadent, przekonany o zniewoleniu przez naturę, odczuwający potrzebę pogrążenia się w nirwanie, postanawia wystąpić przeciw prawom owej natu-

\footnotetext{
${ }^{16}$ Cesare Lombroso (1835-1909) — włoski psychiatra, antropolog i kryminolog, założyciel włoskiej „szkoły pozytywistycznej” kryminologii, propagator antropometrii. Przywołanie tego nazwiska przez Siennickiego wiąże się zapewne z przekonaniem, jakie żywił Lombroso, mianowicie, iż przestępczość jest typową cechą natury ludzkiej, jest dziedziczna, zaś człowieka, który genetycznie pretenduje z wszelkim prawdopodobieństwem do bycia przestępcą, można rozpoznać po kilku fizycznych defektach, które wskazują na atawizm przestępcy. Koresponduje to z poglądem bohatera powieści G. Zapolskiej, że świat jest skażony przestępczością, brzydotą i brutalnością.
}

${ }^{17}$ G. Zapolska, Fin-de-siecleistka, Kraków 1958, s. 392. 
ry, popełniając samobójstwo. Niczym diabeł w swych podszeptach przekonujący do występku, Siennicki stara się przekonać swoją duchową siostrę, panią Świeżawską, by razem z nim, w ostatecznym połączeniu dusz i umysłów, pozbyła się ziemskiej skorupy i poddała się wszechogarniającej i uspokajającej nicości.

Dla Siennickiego samobójstwo jest aktem odwagi — do takiego pojmowania śmierci przekonuje Helenę. Choć dekadenci przez „zdrowych moralnie i duchowo” przedstawicieli społeczeństwa byli pojmowani jako tragizujący, zbytnio rozemocjonowani tchórze, to sami nerwowcy postrzegali śmierć jako wyzwolenie, dowód wolnej woli, ale też świadectwo mądrości i samoświadomości. Dekadent-samobójca w porę zauważa powszechny rozkład i, pragnąc się od brudu świata uwolnić, odchodzi, jednocześnie ocalając swą duchowość, jeszcze nieskażoną pyłem chylącej się ku upadkowi cywilizacji.

Siennicki w nicość chce się pogrążyć wytwornie i poetycznie. Najbardziej spektakularnym elementem ma być otoczenie, w którym dokona on swego żywota. Siennicki wprowadza tytułową fin-de-siecle' istkę do pokoju „pogrążonego w błękitach” ${ }^{18}$, który wywołuje w Helenie skojarzenia najpierw z muślinową suknią jej przyjaciółki, Żabusi, później ze spódniczkami tancerek ${ }^{19}$. Niebieski jest kolorem pełnym symboliki - może odnosić się do świeżości i spokoju, jaki chce osiągnąć bohater; duchowości, jaką pragnie ocalić; może symbolizować otwartą przestrzeń (wodę, morze, niebo), gdzie Siennicki wyzwoli się z pęt cywilizacji; może być także związany z tradycją, wedle której w starożytnej Grecji i Rzymie barwa ta była symbolem najwyższych bóstw (jak bóstwo wolny i samostanowiący o swoim losie i o losie innych chce poczuć się w tym ostatecznym akcie samobójstwa Siennicki). Poczynając od niebieskiej gazy zwieszającej się miękkimi falami z sufitu, niebieskich poduszek i szafirowego dywanu, poprzez subtelne draperie niebieskiej jedwabnej tkaniny na oknach, stropie i ścianach, aż po błękitne tuberozy, anemony i irysy wyściełające podłogę - bohater powieści Zapolskiej stara się odciąć od zwyczajności i codzienności świata. Jak zauważa narrator, „w pokoju nie było ani jednego mebla, nic, co by przypominało prozę codziennego życia" ${ }^{20}$.

Sygnałem odrzucenia przyziemności ludzkiego bytowania na ziemi są rozrzucone między stopami bohaterów kwiaty, które ze względu na swoją egzotykę, wyrafinowanie, tajemniczość, piękno, a także nieoczywistość brzmieniową były modnymi roślinami okresu Młodej Polski ${ }^{21}$. Kwiaty irysów, podobnie jak lilie, oznaczają miłość, wdzięk i samotne piękno, które są tak istotnymi wartościami dla Siennickiego (zwłaszcza

\footnotetext{
${ }^{18}$ Tamże, s. 389.

${ }^{19}$ To wszystko dowodzi, że Helena nie jest zdecydowana na samobójstwo. Przywołuje myśli, które nieodłącznie wiążą się dla niej z życiem, rzeczywistością, światem poza pokojem Siennickiego. Udowadnia to później, gdy, ostatecznie odżegnując się od myśli o samobójstwie, pragnie wrócić do świata na zewnątrz — do Warszawy, ruchu i życia.

${ }^{20}$ Tamże, s. 390.

${ }^{21}$ O symbolice roślinnej i kwiatowej w Młodej Polsce pisze Ireneusz Sikora w książkach Przyroda $i$ wyobraźnia: o symbolice roślinnej w poezji Młodej Polski i Młodopolska florystyka poetycka. Warto także sięgnąć po XIX-wieczne tzw. mowy kwiatów, w których w poetyckiej formie kwiaty same opowiadają o tym, jaka jest ich symbolika.
} 
piękno). Nasuwa się tu także skojarzenie z miłością będącą uczuciem platonicznym, jednakże swoistym związkiem dusz Siennickiego i Heleny. Irysy symbolizują także pogodzenie bogów z ludźmi: Siennicki jest pogodzony ze swoim bogiem-nicością i, decydując się na śmierć, chce ostatecznie przejść do innej przestrzeni bytowej. Tuberoza symbolizuje miłość i bezużyteczne piękno (w Ludziach bezdomnych do tego kwiatu porównany jest lekkoduch Karbowski, który ma na uwadze tylko własne potrzeby, nie czyniąc nic dla dobra ogółu). Za pomocą tego kwiatu Siennicki kreuje wyestetyzowaną przestrzeń, w której pragnie umrzeć — jednakże na przekór symbolice kwiatu piękno sytuacji umierania jest dla niego relewantnym składnikiem ostatniej chwili życia. Tuberoza odwołuje się także do rozbudowanej sfery duchowości bohatera, jest symbolem wewnętrznych dramatów jednostki. Anemon, nazywany Kwiatem Adonisa, co łączy się z pięknem, delikatnością, to symbol przemijalności (odniesienie do krótkotrwałości egzystencji w ogóle, ale też w sensie personalnym — dla Siennickiego samobójstwo to fizyczny koniec, odejście ze świata). Ponadto, w symbolice chrześcijańskiej kwiat ten nawiązuje do przelanej krwi świętych — poprzez strzał z pistoletu Siennicki przelewa własną krew w wykreowanej przez siebie, sakralnej przestrzeni ostatecznego rozrachunku z życiem.

Poetyzacja opisu śmierci następuje nie tylko poprzez zastosowanie semantycznie nacechowanej barwy błękitu, ogarniającej całą przestrzeń, niecodziennie wkomponowanej w pomieszczenie mieszkalne czy poprzez wynikający z tego niebieski półmrok rozświetlany jedynie igrającym, złoto-niebieskim płomieniem lampki, ale też poprzez wyczuwalny dla czytelnika w niezwykle sugestywnym opisie narratora zapach kwiatów, w których po kolana tonie Siennicki. Opis śmierci Siennickiego uruchamia także zmysł dotyku - wyczuwalna jest delikatna struktura jedwabnych tkanin, miękkość płatków kwiatów, zimno marmurowej kolumny.

Jak każdy dekadent nie jest naturalny, korzysta z wielu wystudiowanych, dopracowanych do perfekcji póz. Decyduje się na strzał z rewolweru (gest o iście romantycznej proweniencji). Pamięta o każdym szczególe w swoim wyglądzie: ma na sobie „balowe ubranie" ${ }^{22}$, zaś twarz okalają ze starannością uczesane, błyszczące włosy. Siennicki dba także o to, by nic nie popsuło harmonii scenerii śmierci - gdy Helena zrzuca z siebie ciemne futro, mężczyzna wyrzuca je do przedpokoju, mówiąc: „Nie trzeba, aby ta czarna plama psuła nam harmonię błękitu, prawda?" ${ }^{33}$. Potrzeba ładu realizuje się w radości Siennickiego na widok stroju Świeżawskiej. Cieszy się on, że nieświadomie dopasowała się kolorystyką sukni do błękitu pomieszczenia, w którym mają umrzeć. Stwierdza: „Jak to dobrze, że się pani również niebiesko ubrała, tak się bałem, że pani włoży na siebie suknię ciemną albo brutalnie białą!...”24. Jest to dla niego nie tylko potwierdzenie estetycznej i duchowej zgodności ich dusz, ale też potwierdzenie, że czyn, który planują, jest słuszny i właściwy. Siennicki wydaje się pewny i świadomy

\footnotetext{
22 Tamże, s. 390.

${ }^{23}$ Tamże.

${ }^{24}$ Tamże.
} 
tego, co chce uczynić. Słowa, które kieruje do Heleny, są wypowiedziane wesołym tonem, jego twarz jest jasna i pogodna, lekko, z humorem wypowiada zdanie będące pierwszą aluzją do aktu samobójczego, do jakiego się przygotowywał: „Gość, na którego czekamy, wejdzie zamkniętymi drzwiami!..." ${ }^{25}$. Przybysz-Śmierć z pewnością nie jawi się Siennickiemu jako brzydka kostucha, kobiecy szkielet z kosą i pustymi oczami. Nie było to zgodne z wyrafinowaniem i pięknem, jakiego oczekiwał Siennicki na koniec swego żywota. Wykorzystana została tutaj metafora śmierci jako uspokojenia, odurzenia, wreszcie snu. Jak wspomniano, Siennicki jest niezwykle spokojny i pewny. Przywołuje do siebie Helenę, mówiąc: „Chodź, odpocznij!...”26, układa ją miękko na poduszce, cicho prosi, by zasnęła, jednocześnie sypiąc na nią deszcz kwiatów. Jest to dodatkowe „wgłębienie” przestrzeni powieści — już nie w mieszkaniu Siennickiego, nie w błękitnym pokoju, lecz w leżących na podłodze kwiatach, obsypani, otoczeni zapachem płatków mają dokonać żywota.

Sen, uspokojenie, rozmarzenie, o które bohater prosi Helenę, jest najwyższą rozkoszą, doskonałością i szczęściem. Tego oczekuje od śmierci, z tym wiąże się dla niego odejście ze świata. Motyw śmierci jako snu, uspokojenia jest od wieków znany w literaturze (przykładem Tren XIX Jana Kochanowskiego). Siennicki pragnie umrzeć subtelnie, pięknie, spokojnie, stąd przywoływanie metafory snu będącego w tym przypadku ostatecznym ukojeniem. Siennicki chce odebrać śmierci makabryczny wymiar, niejako wypiera jej krwawy, fizyczny aspekt, skupia się jedynie na tym, że akt samobójczy jest dla niego uspokojeniem, oderwaniem od otaczającego go brudu cywilizacji, w której nie chce już dłużej żyć.

Bohater powieści Zapolskiej starannie i po dandysowsku reżyseruje scenę, na której ma się rozegrać ostatni akt jego życia. Nie pozwala, by cokolwiek odbiegało od ustalonego scenariusza, cokolwiek strywializowało akt, który ma nastąpić. Dlatego z takim zdenerwowaniem reaguje, gdy Helena oskarża go o próbę jej uwiedzenia, nakazując jej nie psuć „banalnym swym skrzekiem uroczej piękności tej chwili!”27. Pokrywając ściany i okna tkaniną, odgradza się od plugawego świata tak, by jego zepsucie nie przeszkadzało mu w uświęconej i poetycznej chwili rezygnacji z życia. Helenie pokój wydaje się „kloszem błękitnym i szklanym” ${ }^{28}$, bez możliwości wyjścia, dla mężczyzny narzucenie zasłon na drzwi prowadzące do przedpokoju jest ostatnim już aktem odgrodzenia od tego, co szkaradne. Bohater chce w tej małej przestrzeni, tonąc w niebieskawym półmroku, po kolana w ulubionych kwiatach, chce w „błękicie i ciszy”29 przeżyć ostatnie chwile żywota. Dzięki drażniącemu zapachowi roślin, przytępiającej zmysł wzroku niebieskiej poświacie pragnie ostatecznie przekonać swą towarzyszkę, by przekroczyła z nim granicę istnienia. I choć Helena Świeżawska ulega chwilowe-

\footnotetext{
${ }^{25}$ Tamże.

${ }^{26}$ Tamże, s. 391.

27 Tamże, s. 392.

${ }^{28}$ Tamże.

${ }^{29}$ Tamże, s. 391.
} 
mu upojeniu perspektywą niebytu, szybko jednak wraca jej zdolność właściwej oceny swych myśli i uczuć, gdyż nie decyduje się na ostateczny krok w nicość. Siennicki, przekonany, że zaplanowana przez niego sztuka śmierci zostanie zrealizowana w każdym szczególe, z okrzykiem Eviva la morte! na ustach strzela do siebie, po czym zapada w błękit otaczających go płatków kwiatów, nieświadom tego, że ziemskie piekło opuszcza samotnie.

Akt samobójczy Siennickiego, pełen subtelności, delikatności, liryzmu (w jego śmierci, podobnie jak w samobójstwie Petroniusza nie ma nic odrażającego) ostatecznie dopełnia czasu jego życia. W obliczu degeneracji świata i degrengolady społeczeństwa piękna śmierć jawi się Siennickiemu jako jedyna droga do zachowania człowieczeństwa.

Samobójczą śmierć bohatera Zapolskiej należy rozważyć nie tylko w kontekście dandyzmu i dekadentyzmu, bowiem przyczyny podjęcia decyzji o zerwaniu więzów ze światem można upatrywać także w gnostyckiej wizji człowieka, życia i umierania ${ }^{30}$. Zgodnie z doktryną gnostycką człowiek żyje w nieprzyjaznym świecie, w który został „wrzucony”. W tej rzeczywistości nie otrzymuje znikąd pomocy, bowiem człowiek i jego życie jest obce Bogu, który nie jest Demiurgiem, lecz nieingerującym w egzystencję ludzką, górującym nad światem bożkiem. Człowiek jest niespójnym, wewnętrznie rozdartym konglomeratem ciała, duszy oraz ducha - tzw. pneumy, która, choć jest prawdziwą jaźnią człowieka, pozostaje równie obca światu jak Bóg. Ponieważ prawa natury zniewalają człowieka, a ciało i dusza są tylko upokorzeniem i upodleniem, jednostka powinna dążyć do uwolnienia pneumy, odcięcia od więzów świata i życia, by móc wrócić do Boga i dopiero tam osiągnąć pełnię. W powieści Zapolskiej Siennicki ujawnia swoją niechęć do upodlającego go ciała, wszechobecnej degrengolady świata, do tego, co szkaradne i upokarzające. Bohater nie czuje się w pełni wolny, wręcz przeciwnie - czuje się spętany więzami życia, wtłoczony we „wstrętny worek"31 ciała, splugawiony egzystencją, którą wiedzie wbrew woli. Dlatego śmierć jest tak upragnionym dążeniem ku prawdziwemu Bogu, przy którym, pozbawiony szkaradnego worka, będzie mógł żyć zgodnie ze swoją „,istotą ”32, wolną i pozbawioną obłudy życia na ziemi.

Kolejnym utworem, którym pragnę się zająć w kontekście poetyzacji śmierci samobójczej, jest Wybraniec losu Włodzimierza Perzyńskiego. Rzeźbiarz Mizerski, bohater noweli, już na początku ukazany jest jako nieszczęśliwy, zamyślony, przygarbiony ciężarem trapiących go zgryzot. Samo nazwisko postaci noweli jest znaczące — koresponduje z poczuciem wewnętrznej pustki i nędzą życiową. To nie dekadenckie rozczarowanie losem jak w przypadku Siennickiego z Fin-de-siecle’istki, jest przyczyną podjęcia

\footnotetext{
${ }^{30}$ Ciekawą perspektywę dla tych rozważań daje praca W. Gutowskiego Gnostyczne światy Mtodej Polski. Prolegomena stanowiąca część obszernej publikacji dotyczącej gnozy w literaturze: Gnoza, gnostycyzm, literatura, red. B. Sienkiewicz, M. Dobkowski, A. Jocz, Kraków 2012, s. 72-96.

${ }^{31}$ G. Zapolska, dz. cyt., s. 392.

${ }^{32}$ Tamże.
} 
decyzji o zakończeniu swego życia. Powód wydaje się bardzo prozaiczny — rzeźbiarza Mizerskiego „zawiodły ambicje i cierpiał najstraszniejszą nędzę"33. Lecz czyż nie ma nic okropniejszego dla jakiegokolwiek twórcy dzieł sztuki, niż szarość i zwyczajność życia? Artysta, kolorowy ptak powinien wieść życie pozbawione problemów przyziemnej natury, wznosić się na wyżyny dzięki sztuce, wyposażony w talent, chęci i natchnienie tworzyć dzieła niezapomniane i wyjątkowe. Jednak rzeźbiarzowi Mizerskiemu daleko do takiego ideału egzystencji artysty — posiadając „niepospolity talent i wiele szczerego zapału do pracy" ${ }^{34}$, odczuwa brak materiału, w którym mógłby rzeźbić. Przygnieciony problemami jako człowiek i twórca decyduje się zakończyć swe życie, lecz — o ironio! - nie posiada „materiału” do popełnienia samobójstwa. Narrator wyrá́nie traktuje swojego bohatera z humorem, nie stara się udramatycznić jego historii. W narracji obecna jest ironia, dystans opowiadającego wobec postaci noweli, która traktowana jest z przymrużeniem oka (znakiem tej ironii będzie dalej fakt, iż do samobójstwa, do którego Mizerski z takim uporem postanowił dążyć, ostatecznie nie dochodzi).

Nie przyczyny niedoli bohatera noweli Perzyńskiego, które skłoniły go do poszukiwania sposobu odejścia z tego świata, nawet nie sam czyn samobójczy, są bowiem dla niego istotne. Najważniejszy jest rodzaj śmierci. Na decyzję rzeźbiarza w tej materii nie ma wpływu ani logika, ani zdroworozsądkowe myślenie, ani umiejętność zaakceptowania trudnych, choć niemożliwych do zmiany warunków. Narrator częściowo wyjaśnia przyczyny takiego uporu przy wyborze konkretnego sposobu odejścia ze świata, tłumacząc to skomplikowaną naturą, jaką obdarzeni są artyści. Niewątpliwie, pragnienie bohatera, który chce zginąć od strzału z rewolweru, „od kuli jak żołnierz na polu bitwy"35 (czyli zaszczytnie, godnie, w obronie wyższych wartości, w tym przypadku życia niebanalnego, autonomii, możliwości decydowania o sobie, artyzmu, sztuki), wynika z profesji, jaką wykonuje i związanych z tym określonych estetycznych zapatrywań. Artyści są bowiem istotami niejednoznacznymi, ekscentrycznymi, które wielkością geniuszu i ogromem obowiązku duchowego przewodnictwa nad narodem są tłumaczone z wszelkiego rodzaju kaprysów. Ponadto, każdy artysta, posiadając wyczuloną wrażliwość na piękno, odczuwając wybitną potrzebę obecności tegoż piękna w życiu, będzie odżegnywał się od tego, co szpetne i ordynarne. Dla rzeźbiarza Mizerskiego każdy rodzaj śmierci, oprócz wymarzonego strzału z rewolweru, jest czymś godnym pogardy, czymś porażającym brzydotą. Śmierć przy użyciu pistoletu jest bowiem czymś świetnym, przydającym chwały, kojarzy się z chwalebnym i godnym umieraniem żołnierza w czasie walki. Rzeźbiarz Mizerski nie chce, nawet będąc w stanie dużej desperacji, sięgnąć po środki, które nie są stosowne artyście - człowiekowi uduchowionemu, wrażliwemu, rozwiniętemu intelektualnie.

${ }^{33}$ W. Perzyński, Wybraniec losu, [w:] tenże, Nowele, wyb. K. Pawłowska-Najder, Warszawa 1956, s. 167.

${ }^{34}$ Tamże, s. 168.

${ }^{35}$ Tamże. 
Można by przypuszczać, że problemy Mizerskiego nie są aż tak przytłaczające, skoro w obliczu niemożności zdobycia pieniędzy na upragniony rewolwer, rzeźbiarz nie decyduje się na inny sposób zakończenia swego życia, „wyskakując z okna albo rzucając się pod pociąg" ${ }^{\prime 6}$. Jednakże to nie świadczy o wadze problemów, z jakimi zmagał się na co dzień i które stały się impulsem do podjęcia decyzji o samobójstwie. Ten upór i wytrwałość $\mathrm{w}$ raz powziętym zamiarze świadczą o wadze, jaką przywiązuje bohater małej prozy Perzyńskiego do umierania. Skoro nie może on decydować o swoim życiu, mieć wpływu na poprawę swego losu, chce wyreżyserować swoje samobójstwo, świadomie wybierając narzędzie śmierci.

W noweli Perzyńskiego nie tyle życie, ile wyobrażenie o tym, jak ta egzystencja mogłaby wyglądać, wiąże się ze śmiercią i potrzebą uczynienia ze sztuki nadrzędnego czynnika porządkującego byt i nie-byt. Jak już zostało wspomniane, Mizerski jest utalentowany, pełen zapału, z ogromnymi ambicjami, dodatkowo posiada także wiele wartościowych przymiotów psychofizycznych — jest przystojny, silny, dobrze zbudowany, miły i sympatyczny. Jest artystą z powołania i z tytułu, jego artyzm tkwi w duszy, niestety nie tworzy dzieł z powodu braków finansowych i nieumiejętności zaskarbiania sobie łask odpowiednich osób. Ta tak zwana „moralna sztywność karku” ${ }^{37}$, jak to określa narrator, także dowodzi, jak arystokratycznym z ducha, dumnym i nieugiętym był rzeźbiarz Mizerski - nawet w obliczu nędzy, upadku, głodu nie upadla się, nie zniża się do kolan bogatych, by prosić o jałmużnę. Woli przejść przez życie z uniesioną głową, godności upatrując nie w zbytkownym życiu, lecz w wytrwałości, uczciwości, w postawie czysto ludzkiej. Umiejętność znalezienia wartości wyższych niż zaspokajanie przyziemnych potrzeb fizjologicznych takich jak głód, chłód i pragnienie objawia się także w tym, że bohater nie pozwala sobie ze względu na "zrozumiały pietyzm" ${ }^{38}$ oddać na makulaturę licznych egzemplarzy tomiku poezji autorstwa zmarłego poety, przyjaciela bohatera, by mieć pieniądze na jedzenie. Zamiast tego z tychże tomików, w obliczu nędzy życiowej, w skromnym mieszkanku tworzy sobie łoże godne artysty — może nie spełniające kryterium miękkości i wygody, ale z pewnością oryginalne i wyjątkowe. Te wszystkie przykłady wyjaśniają nieco, dlaczego skazany na nędzę artysta-rzeźbiarz raz powziąwszy decyzję o zakończeniu życia, nie wybiera jakiegokolwiek narzędzia, byle tylko zakończyć swe ziemskie męki.

Okoliczności życiowe, które stały się udziałem bohatera Wybrańca losu, sprawiły, że możliwe jest tylko przypuszczanie, czy rzeźbiarz równie uparcie starałby się zdobyć rewolwer, czy wreszcie dokonałby aktu samobójstwa oraz jak ten akt by wyglądał. Można się tylko domyślać, czy Mizerski chciałby uczynić ze swej śmierci widowisko dla wielu osób, czy pragnąłby zginąć w ciszy swej pustej pracowni. Jedno jest pewne — los dał swemu wybrańcowi szansę na to, by mógł tworzyć sztukę i piękno wprowadzać w życie, nie w śmierć. Czy słusznie — to już jest temat dla rozważań w odrębnej pracy.

\footnotetext{
36 Tamże.

${ }^{37}$ Tamże, s. 169.

38 Tamże.
} 
W Historii piękna Umberto Eco nie pisze nic o pięknym umieraniu. Samobójcy od zawsze są wykluczani poza margines społeczeństwa, uznani za jednostki nie potrafiące poradzić sobie z problemami. Jednakże w analizowaniu literackich obrazów śmierci samobójczych należy wyzbyć się myślenia schematami, zrezygnować z rozpatrywania wszystkiego na zasadzie antynomii dobro — zło, zmienić perspektywę i poniechać oceny. Na bohaterów-samobójców należy spojrzeć z ich punktu widzenia — piękna, upoetyczniona śmierć stanowi albo dopełnienie pięknego życia, albo rekompensatę z powodu egzystencji przyziemnej, banalnej. Należy też wyzbyć się myślenia, że samobójstwo to akt słabości, zaś człowiek zadający sobie śmierć sprzeciwia się normom prawa ludzkiego i przykazaniom danym od Boga chrześcijańskiego. Rezygnacja z życia to dla nich manifest odwagi, zaś potrzeba jej poetyzacji to próba poszukiwania piękna w chwili ostatecznej. Nie sam akt, nie jego moralne konsekwencje czy społeczne skutki są istotne dla literackich „pięknych samobójców”, jeśli mogę użyć takiego sformułowania, najważniejsze jest upoetyzowanie tego, co dla ogółu jest występkiem, a dla nich jest intymnym i prywatnym wyznaniem własnej woli.

Anna Kaźmierska

\section{A Poetic Death — the Literary Images of Suicidal Deaths in the Literature OF NinETEenth Century}

\section{Summary}

There exists something like beautiful life. Is it possible to die beautifully? Is there a beauty that can be related to something as terrifying as suicidal dying? The study presents attempts of making the death poetic by the characters that emerged in opuses of the authors of the nineteenth century. The paper shows the reasons why these characters tried to die in a sophisticated way, which cannot be trivial at all. The author of this study attempts to explain why they make their death look like a performance. And the number of viewers is not the most important issue they are worrying about. What is really meaningful is to tear the constraints which are imposed by society, culture, people's demands and to achieve the liberation from life's and death's schemes. The main premise of the paper is that, for all characters, the suicidal death is most of all the manifestation of their own need to decise about themselves and to explore an art in every detail of people's existence. The discussed phenomena are illustrated in the novels of Henryk Sienkiewicz, Gabriela Zapolska and Włodzimierz Perzyński. 